\title{
Potentiality of caro's acid in leaching of uranium and radioactive measurements from Abu-Rusheid mylonitic gneiss rocks, South Eastern Desert, Egypt
}

M S Nagar ( $D$ mf_nagar@yahoo.com )

Nuclear Materials Authority

W M morsy

nuclear materials authority

M B Bayoumi

nuclear materials authority

A S Shalan

nuclear materials authority

\section{Research Article}

Keywords: Uranium dissolution, Caro's acid, oxidation, kinetics, shrinking core models, Abu Rusheid area

Posted Date: July 13th, 2021

DOI: https://doi.org/10.21203/rs.3.rs-662542/v1

License: (c) This work is licensed under a Creative Commons Attribution 4.0 International License. Read Full License 


\section{Abstract}

Abu Rusheid area is located at the Southern Eastern Desert of Egypt and composed of Mylonitic gneiss rocks (mineralized rock), Serpentinite rocks, Ophiolitic metagabbro, Ophiolitic mélange, Monzogranites, post- granitic dykes (lamprophyre and dolerite), veins and recent alluvial deposits. This paper is concerned with the study of potentiality of sulphuric and caro's acid in uranium dissolution from Abu Rusheid mineralized rocks. For this purpose, many batch dissolution experiments were conducted. The obtained results showed that $91.5 \%$ and $52 \%$ uranium leachability for Caro's acid and dilute sulfuric acid respectively. The reaction mechanism was described using shrinking core models.

\section{Introduction}

Resulted of many Exploration activities for uranium resources at south Eastern Desert of Egypt, the discovery of hot gneiss rocks ( $\mathrm{U}, \mathrm{Th}, \mathrm{Nb}, \mathrm{Ta}, \mathrm{Zr}, \mathrm{Pb}, \mathrm{Y}, \mathrm{Zn}, \mathrm{W}, \mathrm{Sn}$ and $\mathrm{Ga}$ ), in Wadi (W.) Abu Rusheid area, cut by lamprophyre dykes bearing mineralization ( $U$, REEs, $\mathrm{Pb}, \mathrm{Ag}$ and $\mathrm{Zn}$ ) along two shear zones [1-4] as well as, low grade metamorphosed sandstone type-uranium deposit ( $U$ and Mo) in W. Sikait,4 km from W. Abu Rusheid [5].

The Abu Rusheid area is located in Egypt's Eastern Desert, approximately $95 \mathrm{~km}$ southwest of MarsaAlam City. Latitudes $24^{\circ} 36^{\prime} 29^{\prime \prime}$ and $24^{\circ} 39^{\prime} 22^{\prime \prime} \mathrm{N}$, and Longitudes $34^{\circ} 44^{\prime} 40^{\prime \prime}$ and $34^{\circ} 47^{\prime} 23^{\prime \prime} \mathrm{E}$, define its boundaries. The gneiss rocks are characterized by regional WNW-ESE thrusting and polycyclic deformation and metamorphism. The age of this thrusting is estimated to be between $682 \mathrm{Ma}$ (when the older granitoids were deposited) and 565 to $600 \mathrm{Ma}$, the time of intrusion of the younger granites [6].

The rocks are heavily deformed in general, with a marked progression from low-grade green schist facies to medium-grade amphibolite facies (Staurolite - Kyanite - Silliminite facies) [7, 8]. Uraninite and pitchblende are primary uranium ores that are found mostly in veins or pegmatites, but also in sedimentary and placer deposits [9]. In weathered zones of initial deposits, secondary uranium ores are identified and precipitated in sediments. Autinite, torbernite, uranophane, carnotite, and schoepite are some of these minerals [10]. Primary uranium is lowering soluble in both dilute acid and carbonate (alkali) solutions than secondary one. So that it economically performs the uranium leaching on proper oxidizing conditions to achieve high uranium extraction.

Uranium leachability is directly proportional to the free acidity of leach solution which range from 20 to $100 \mathrm{~g} / \mathrm{L}$. However, the using acid leaching medium should not be too strong; very high proton concentrations inhibited the oxidation of $U^{4+}$ to $U^{6+}[11]$. At concentrations higher than $200 \mathrm{~g} / \mathrm{L}$ the leaching response was inhibited [12]. This consequently leads to an increase in the leachability of other gangues metals associated uranium.

Several trails around the world use, an oxidant such as sodium chlorate, hydrogen peroxide $\left(\mathrm{H}_{2} \mathrm{O}_{2}\right)$ and pyrolusite. But that use resulted in accumulating the heavy metal manganese and sodium chloride as the major contaminant in the acidic waste, which restricts its recycling to the mill [13]. Iron oxides minerals 
such as Hematite and magnetite could be played as oxidizing agent in uranium dissolution process since oxidizing the $\mathrm{U}^{4+}$ to $\mathrm{U}^{6+}$ as in the following eqns:

$\mathrm{MnO}_{2}+2 \mathrm{Fe}^{2+}+4 \mathrm{H}^{+} \rightarrow 2 \mathrm{Fe}^{3+}+\mathrm{Mn}^{2+}+2 \mathrm{H}_{2} \mathrm{O}(1)$

$\mathrm{UO}_{2}+2 \mathrm{Fe}^{3+}+3 \mathrm{H}_{2} \mathrm{SO}_{4} \rightarrow \mathrm{UO}_{2} \mathrm{SO}_{4}+2 \mathrm{FeSO}_{4}+6 \mathrm{H}^{+}(2)$

Caro's acid is the best alternative oxidant to pyrolusite and sodium chlorate. Since, it was easier to handle, provided better control and a completely automated system, ensured continual oxidant supply and almost eliminating manganese from waste effluents $[14,15]$.

Batch leaching tests on Ranger, Nabarlek, Koongarra, and Jabiluka ores showed that uranium extraction was unaffected by choice of oxidant, but that Caro's acid reduced acid and lime requirements by $15-25 \%$ and $20-30 \%$ respectively[16]. To gain a better understanding of the leaching process and its operation, kinetic studies should be concerned. Since the leaching kinetics interprets the complex behavior of leaching process occur on grain particles [17]. Thus, this study includes investigation and discussion of the leaching kinetics and dissolution of uranium on Caro's acid solution.

For leaching uranium from Abu-Rusheid uranium mineralization, phosphoric acid was examined. Results obtained encourage recommending phosphoric acid as an alternative to sulphuric acid leaching agent for uranium [18]. It is demonstrated by the laboratory experiment that heap leaching is suited to process AbuRusheid uranium mineralization; D263B strong base anion resin can effectively concentrate and purify the obtained pregnant solutions to produce a quality products, namely yellow cake [19].

The present paper concerned with study the leachability of Abu Rusheid uranium minerals ores situated at the Southern Eastern Desert of Egypt. The potentiality of Caro`s acid was established in batch experiments followed by kinetics investigation.

\section{Geologic Setting}

\section{Regional geology}

Abu Rusheid is a small part of the Arabian-Nubian Shield that outcrops across an area of around 73.5 $\mathrm{km}^{2}$ in Egypt's South Eastern Desert (ANS). The shield, which covers more than $6 \times 10^{6} \mathrm{~km}^{2}[20,21]$, is one of the world's greatest Neoproterozoic crustal development episodes, having been exposed by uplift and erosion during the Oligocene and younger periods [22, 23]. The Arabian-Nubian Shield (ANS) is made up of Precambrian rocks that can be found in western Arabia and northeastern Africa on both sides of the Red Sea (Fig. 1a; [24]). The majority of the ANS is made up of juvenile continental crust [25-27], which crust is formed by mantle-derived melts. When the Mozambique ocean closed due to arc terrane accretion, it formed between 900 and $550 \mathrm{Ma}$ [22]. Abu Rusheid area is a part of the Arabian-Nubian Shield and can be considered a key domain in that shield, beside its very complex structures. In addition, this area is considered as the southeastern extension of the Migif-Hafafit metamorphic complex [28-30], 
which is highly tectonized and characterized by presence of several types of mineralization and alteration processes along time spans. Abu Rusheid-Sikait area is bordering to the major shear zone recognized by many authors as the Nugrus thrust fault [31] or the Nugrus strike-slip fault [32] and or Shait-Nugrus shear zone [33].

\section{Geology of the study area}

The main rock units encountered in this area are grouped from older to younger as follows; - (a) Mylonitic gneiss rocks, (b) Serpentinite rocks, (c) Ophiolitic metagabbro, (d) Ophiolitic mélange, (e) Monzogranite rocks, (f) Post-granitic dykes and veins (Fig. 1b). The mylonitic gneiss rocks $\left(2.0 \mathrm{~km}^{2}\right)$ represent the oldest rocks exposed in W. Abu-Rusheid area. These mylonitic gneisses were originally identified as psammitic gneisses [34-37], occur in the field down thrusted the ophiolitic mélange and foliated in ENEWSW direction (Fig. 2a). The mylonitic gneiss rocks of Abu Rusheid area is characterized by development of mylonitic fabric close to the shear and contact zones, low to moderate topography and highly sheared as well as show a well-developed planer banding, gneissosity and folding. They are highly metasomatized and reflect high radioactive anomalies that contain abundant crystals of thorite, uranothorite, zircon, fluorite and $\mathrm{Nb}$-bearing minerals (samarskite, pyrochlore, betafite) [38]. They are cross cut by three main shear zones; the first two shear zones are parallel to each other (NNW-SSE) and perpendicular to the third one (ENE-WSW), the NNW-SSE shear zones were emplaced by lamprophyre dykes which act as a good barrier (physical and chemical trap) capturing, adsorbing and protecting the uranium minerals that introduced to the gneiss with moving the uranium-rich hydrothermal solution (Fig. 2b-d). They have general NNW trend and dips steeply $\left(80^{\circ}-85^{\circ}\right)$ toward SW. The serpentinite is only found in a small part in the NW corner of the mapped area. Abu-Rusheid -Sikait granitic pluton is an elongated body extending NW-SE for about $12 \mathrm{~km}$ with width about $3 \mathrm{~km}$. The granitic rocks occupy the major part of the mapped area surrounding the mylonitic gneisses (Fig. 1b). They are represented from the NW direction by porphyritic biotite monzogranite followed by deformed biotite monzogranite and two mica monzogranite, whereas the muscovite granites occupy the SE part of the pluton [39].

\section{Characteristics of the Radioactive Mineralization}

The mylonitic gneiss rocks are characterized by well-developed $\mathrm{Li}, \mathrm{U}, \mathrm{Th}, \mathrm{Nb}, \mathrm{Y}, \mathrm{Au}, \mathrm{As}, \mathrm{Pb}, \mathrm{Zn}, \mathrm{Sn}$ and $\mathrm{Cu}$ enrichments respectively. The common minerals that have been recognized in both mylonitic gneiss and lamprophyres are represented by zinnwaldite, U- minerals (soddyite, uranophane, autunite, kasolite, torbernite and meta- zeunerite) (Fig. 3a,b), Th-minerals (thorite and uranothorite), and gold, cassiterite, scheelite, xenotime $(\mathrm{Y})$, allanite, zircon, fluorite, monazite $(\mathrm{Ce})$ and $\mathrm{Nb}$-Ta minerals. Thorium minerals (thorite and uranothorite) are clear in gneissic rocks only. Others minerals were recorded and studied such as(sulphides,tin, zinc-manganese minerals, fluorite, xenotime, zircon, allanite, monazite, iron oxide minerals, clay minerals (illite + kaolinite) and calcite and micas at Abu Rusheid area [4]. The average U/ Th ratio in mylonite and lamprophyre dykes (1.32 and 40.0) is exceeding than average of crust (0.33), illustrate uranium gain, whereas in mylonitic gneiss samples, their $\mathrm{U} / \mathrm{Th}$ ratio $(0.24)$ is less than the average of crust, denote uranium loss. 
The descending (infiltrational) mineralization-bearing hydrothermal solutions are mainly derived from meteoric water, migrating under gravity from high relief peripheral hot uraniferous muscovite-biotite granite to low central part of the basin (mylonitic gneiss rocks) and redeposited along banding planes and fractures in mylonitic gneiss .

After the emplacement of lamprophyre dykes (mantled-derived with high temperature and volatiles, as well as, $\mathrm{CO}_{2}$ ), the ascending (exfiltrational) hydrothermal solutions are dominantly derived from groundwater, and are mainly derived by high gas pressures penetrating into the basin, along banding planes and fractures in the host rocks with low temperatures and containing $\mathrm{F}^{-}$and $\mathrm{CO}_{3}{ }^{2-}, \mathrm{PO}_{4}{ }^{3-}$ and $\mathrm{H}_{2} \mathrm{O}$ caused redistribution; transportation and redeposition of the base metals ( $\mathrm{Pb}, \mathrm{Zn}, \mathrm{Cu}$ and $\mathrm{As}$ ), precious metals ( $\mathrm{Au}$ and $\mathrm{Ag}$ ) and in HFSE (e.g. Nb, HREE and Y), along the channel ways (banding of the gneissic rocks and fractures) to the shear zones (NNW-SSE) and precipitated in boxworks and adsorbed on clay minerals.

The lamprophyre dykes and mylonitic gneiss are characterized by ferrugination (high total iron). The latter indicates the presence of alkali hydrothermal solution, may precipitate $\mathrm{Fe}^{+3}$ and $\mathrm{U}^{+6}$ within microfractures in the form of iron-oxy-hydroxides rich in uranium. The occurrences of U-minerals in the pores (fractures and veins) indicate that, these minerals were deposited from solutions descending or ascending that permeated the micro-porous. Desulfidization process took place in the mylonitic gneiss rocks and lamprophyre dykes, where sulfide minerals such as pyrite, chalcopyrite and sphalerite are easily oxidized by ground water in the presence of oxygen to produce either ferric oxide or its hydrate analog, leaving box works. The release of $\mathrm{Ca}$ and $\mathrm{F}$ during illitization of plagioclases and biotite may combine together to form calcium fluoride $\left(\mathrm{Ca}_{2}\right)$. This kind of alteration by acid solution is responsible for leaching mineralization from the banded mylonitic gneiss rocks, transported and adsorbed on the margins of NNW-SSE lamprophyre dykes (chemical trap for mineralization).

\section{Experimental}

\section{Characterization of Abu Rusheid mylonite uranium mineralization}

Abu Rusheid mylonite representative samples were collected from Abu Rusheid area which is located in the South Eastern Desert, Egypt. The ore sample was firstly crushed to $297 \mu \mathrm{m}$ and $149 \mu \mathrm{m}$ then ground to $74 \mu \mathrm{m}$ particle sizes. Sample characterization by XRF showed the presence of $\mathrm{Ba}, \mathrm{Pb}, \mathrm{Fe}, \mathrm{Mo}, \mathrm{Nb}, \mathrm{Zr}, \mathrm{Y}$, $\mathrm{Sr}, \mathrm{U}, \mathrm{Zn}, \mathrm{Mn}, \mathrm{Ca}, \mathrm{K}, \mathrm{S}, \mathrm{Si}$ and $\mathrm{Al}$. The representative sample is characterized chemically as major and trace elements by ignition at $1000^{\circ} \mathrm{C}$ before preparing solutions $\mathrm{A}$ and $\mathrm{B}$ of Shapiro and Brannock method for analysis of silicate rock [40]. Uranium analysis was performed spectrophotometrically in low concentrations using Arsenazo (I) method [41], while in high concentrations by titration against ammonium meta vanadate [42]. 
Analysis performed using UV-spectrophotometer "single beam multi-cells-positions model SP-8001", Metretech Inc., version 1.02.

\section{Leaching Experiments}

Leaching experiments were conducted with a conical flask placed in a constant temperature water bath, with mechanical stirring and a thermometer for temperature control. $250 \mathrm{~g}$ of representative sample was introduced into the reactor to yield a solid/liquid ratio of 1/3. After leaching, the sample was washed with acidified water. The effects of changing various parameters such as sulfuric acid and $\mathrm{H}_{2} \mathrm{O}_{2}$ concentration, temperature, leaching time, grin size, $\mathrm{S} / \mathrm{L}$ ratio and Eh were investigated. Used reagents $\left(\mathrm{H}_{2} \mathrm{SO}_{4}\right.$ and $\left.\mathrm{H}_{2} \mathrm{O}_{2}\right)$ are of the analytical grade. Eh and $\mathrm{pH}$ were measured accurately using the $\mathrm{pH}$ - meter model (HAANA pH-mV-temp).

\section{Radioactive measurements}

Equivalent uranium and thorium contents were determined radiometrically by using multi-channel analyzer Gamma-ray detector (Gamma-spectrometer technique) in the Laboratories of the Nuclear Materials Authority, Egypt. The studied samples are crushed to about 100 mesh then the containers is filled with about 300-400gm of the crushed samples, sealed well and left for at least 21 days to accumulate free radon for attaining radioactive equilibrium. The measurements are expressed in (ppm) for eU \& eTh.

\section{Results And Discussion}

\section{Radioactivity of the Abu Rusheid mylonitic gneiss samples,}

The radioactivity of the studied mylonitic gneiss samples, Abu Rusheid area, SED, Egypt were measured then related to the standards for $U$ and Th provided by International Atomic Energy Agency (IAEA). The measurements are given in Table. 1. The table shows that the eU shows very high level from 69 and 1106 ppm with an average of $364.84 \mathrm{ppm}$, while the eTh content ranges between 45 and 402 ppm with an average of $147.59 \mathrm{ppm}$. The eTh/eU ratios range from $0.04-5.43$ with an average of about 0.86 . These values indicated that; there is uranium leach in. On the eU-eTh plot Fig. (4a); eU shows very high level and show the relationships among $\mathrm{eU}$ and $\mathrm{eTh}$ for the mineralized mylonitic gneiss, where the relation of eU and eTh is negative due to the slight enrichment of uranium. The increase of eTh content in some samples is regard due to the presence of uranothorite. Also, the eTh/eU ratio versus eU (Fig. 4b) show negative correlation, in which $\mathrm{eTh} / \mathrm{eU}$ ratio increases with a decrease of eU in the most of representive samples reflect the presence of enrichment uranium mineralization.

Table. $1 \mathrm{eU}(\mathrm{ppm}), \mathrm{eTh}(\mathrm{ppm})$ contents and eTh/eU ratios of the studied mylonitic gneiss samples,

\section{Abu Rusheid area, SED, Egypt.}




\begin{tabular}{|llllllll|}
\hline S. No & eU & eTh & eTh/eU & S. No & eU & eTh & eTh/eU \\
\hline $\mathbf{1}$ & 161 & 240 & 1.49 & $\mathbf{2 3}$ & 312 & 143 & 0.46 \\
\hline $\mathbf{2}$ & 125 & 178 & 1.42 & $\mathbf{2 4}$ & 241 & 189 & 0.78 \\
\hline $\mathbf{3}$ & 166 & 171 & 1.03 & $\mathbf{2 5}$ & 168 & 288 & 1.71 \\
\hline $\mathbf{4}$ & 172 & 230 & 1.34 & $\mathbf{2 6}$ & 532 & 92 & 0.17 \\
\hline $\mathbf{5}$ & 122 & 246 & 2.02 & $\mathbf{2 7}$ & 392 & 104 & 0.27 \\
\hline $\mathbf{6}$ & 134 & 220 & 1.64 & $\mathbf{2 8}$ & 632 & 169 & 0.27 \\
\hline $\mathbf{7}$ & 141 & 174 & 1.23 & $\mathbf{2 9}$ & 69 & 90 & 1.30 \\
\hline $\mathbf{8}$ & 94 & 334 & 3.55 & $\mathbf{3 0}$ & 106 & 169 & 1.59 \\
\hline $\mathbf{9}$ & 74 & 402 & 5.43 & $\mathbf{3 1}$ & 215 & 118 & 0.55 \\
\hline $\mathbf{1 0}$ & 174 & 162 & 0.93 & $\mathbf{3 2}$ & 823 & 60 & 0.07 \\
\hline $\mathbf{1 1}$ & 128 & 125 & 0.98 & $\mathbf{3 3}$ & 894 & 103 & 0.12 \\
\hline $\mathbf{1 2}$ & 124 & 95 & 0.76 & $\mathbf{3 4}$ & 912 & 84 & 0.09 \\
\hline $\mathbf{1 3}$ & 178 & 147 & 0.82 & $\mathbf{3 5}$ & 944 & 79 & 0.08 \\
\hline $\mathbf{1 4}$ & 159 & 66 & 0.41 & $\mathbf{3 6}$ & 1044 & 47 & 0.04 \\
\hline $\mathbf{1 5}$ & 264 & 213 & 0.81 & $\mathbf{3 7}$ & 1106 & 115 & 0.10 \\
\hline $\mathbf{1 6}$ & 86 & 63 & 0.73 & $\mathbf{3 8}$ & $\mathbf{7 4 3}$ & 109 & 0.15 \\
\hline $\mathbf{1 7}$ & 113 & 51 & 0.45 & $\mathbf{3 9}$ & $\mathbf{7 5 1}$ & 48 & 0.06 \\
\hline $\mathbf{1 8}$ & 320 & 45 & 0.14 & $\mathbf{4 0}$ & 919 & 98 & 0.11 \\
\hline $\mathbf{1 9}$ & 437 & 122 & 0.28 & $\mathbf{4 1}$ & 372 & 136 & 0.36 \\
\hline $\mathbf{2 0}$ & 418 & 106 & 0.25 & $\mathbf{4 2}$ & 321 & 124 & 0.38 \\
\hline $\mathbf{2 1}$ & 133 & 162 & 1.22 & $\mathbf{4 3}$ & 267 & 177 & 0.66 \\
\hline $\mathbf{2 2}$ & 157 & 181 & 1.15 & $\mathbf{4 4}$ & 410 & 219 & 0.53 \\
\hline & & & & Average & $\mathbf{3 6 4 . 8 4}$ & $\mathbf{1 4 7 . 5 9}$ & $\mathbf{0 . 8 6}$ \\
\hline
\end{tabular}

\section{Chemical characterization of uranium mineralization sample}

Analysis of the working technological uraniferous mylonite sample has revealed a uranium assay of 400 ppm. Major elements analyzed involved $73.8 \% \mathrm{SiO}_{2}, 11.9 \% \mathrm{Al}_{2} \mathrm{O}_{3}$ and $2.9 \%$ total iron as $\mathrm{Fe}_{2} \mathrm{O}_{3}$ as shown 
in Table (2) as well as some trace elements. The leaching of uranium minerals by sulfuric acid requires the presence of $\mathrm{Fe}^{+3}$ in order to oxidize $\mathrm{U}^{+4}$ to $\mathrm{U}^{+6}$ to form $\mathrm{U}\left(\mathrm{SO}_{4}\right)^{-4}$ dissolved in leach liquor but $\mathrm{Fe}^{+2}$ is abundant than $\mathrm{Fe}^{+3}$ in the studied sample. Thus, it's necessary to presence of oxidant to oxidize $\mathrm{Fe}^{+2}$ to $\mathrm{Fe}^{+3}$, which their presence serves an electron transfer catalyst between an oxidant and $\mathrm{UO}_{2}[43]$.

$\mathrm{UO}_{2}+2 \mathrm{Fe}^{3+}+3 \mathrm{H}_{2} \mathrm{SO}_{4} \rightarrow \mathrm{UO}_{2} \mathrm{SO}_{4}+2 \mathrm{FeSO}_{4}+6 \mathrm{H}^{+}(1)$

Table 2

The rock composition of Abu-Rusheid technological sample

\begin{tabular}{|llll|}
\hline Oxides & $\mathbf{W t} \%$ & Trace elements & ppm \\
\hline $\mathrm{SiO}_{2}$ & 73.8 & $\mathrm{Nb}$ & 680 \\
\hline $\mathrm{TiO}_{2}$ & 0.1 & $\mathrm{Zr}$ & 2650 \\
$\mathrm{Al}_{2} \mathrm{O}_{3}$ & 13.9 & $\mathrm{Y}$ & 750 \\
\hline $\mathrm{Fe}_{2} \mathrm{O}_{3}$ & 0.7 & $\mathrm{~Pb}$ & 800 \\
\hline $\mathrm{FeO}$ & 2.2 & $\mathrm{Ga}$ & 85 \\
\hline $\mathrm{MnO}$ & 0.1 & $\mathrm{Cu}$ & 190 \\
\hline $\mathrm{MgO}$ & 0.85 & $\mathrm{Zn}$ & 1450 \\
\hline $\mathrm{CaO}$ & 0.67 & $\mathrm{U}$ & 400 \\
\hline $\mathrm{Na}_{2} \mathrm{O}$ & 3.0 & $\mathrm{Th}$ & 573 \\
\hline $\mathrm{K}_{2} \mathrm{O}$ & 4.3 & $\mathrm{Nd}$ & 84 \\
\hline $\mathrm{P}_{2} \mathrm{O}_{5}$ & 1.06 & $\mathrm{As}$ & 12 \\
\hline $\mathrm{L} . \mathrm{O} . \mathrm{I}$ & 0.16 & $\mathrm{Sn}$ & 21 \\
\hline
\end{tabular}

Nerenest derived Eq. (1); could follow the ferric iron concentration on leach liquor, since it's correlated the redox potential with $\mathrm{Fe}^{+3} / \mathrm{Fe}^{+2}$ ratio:

$E c=397+0.1984 \mathrm{~T} \log ([\mathrm{Fe} 3+] /[\mathrm{Fe} 2+])$,

Where $\mathrm{Ec}$ is is the solution potential relative to the saturated calomel electrode $(\mathrm{mV})$ at $35^{\circ} \mathrm{C}, \mathrm{T}$ is in $\mathrm{K}$. The another model equation is predicted from plant data of hartebeestfontein operation:

$E c=399.8+0.14 \log A+0.2 \log ([\mathrm{Fe} 3+] /[\mathrm{Fe} 2+])$

Where $A$ is the sulfuric acid concentration $(\mathrm{g} / \mathrm{L})$ [44]. 
The presence of $\mathrm{MnO}(0.1 \%)$ in mineralized ore could be useful as oxidant of iron as in the following Eq. (2)

$2 \mathrm{Fe}^{2+}+\mathrm{MnO}_{2}+4 \mathrm{H}^{+} 2 \mathrm{Fe}^{3+}+\mathrm{Mn}^{2+}+2 \mathrm{H}_{2} \mathrm{O}(2)$

The above equation shows that the reaction requires large amounts of hydrogen ions to take place, which consequently consume the acid leach.

The acid required to achieve the pervious equivalent oxidation of ferrous ion could be reduced by $50 \%$ if using another oxidant such as sodium chlorate or Caro `s acid as evident in the following equation: $2 \mathrm{Fe}^{2+}$ $+\mathrm{H}_{2} \mathrm{SO}_{5}+2 \mathrm{H}^{+} 2 \mathrm{Fe}^{3+}+\mathrm{H}_{2} \mathrm{SO}_{4}+2 \mathrm{H}_{2} \mathrm{O}(3)$

$2 \mathrm{Fe}^{2+}+1 / 3 \mathrm{ClO}_{3}^{-}+2 \mathrm{H}^{+} 2 \mathrm{Fe}^{3+}+1 / 3 \mathrm{Cl}^{-}+2 \mathrm{H}_{2} \mathrm{O}(4)$

The Nabarlek mill in Northern Australia use Caro's acid $\left(\mathrm{H}_{2} \mathrm{SO}_{5}\right)$ as oxidant agent which manufactured on site by the reaction of concentrated sulfuric acid with $50-70 \%$ hydrogen peroxide in ratio of 3:1. Because of its greater stability, Caro's acid is a more efficient oxidant than hydrogen peroxide itself [45].

Potentiality of Caro's acid of uranium dissolution from Abu Rusheid mineralized sample was investigated by performs batch experiments as the following;

\section{Relevant dissolution factors}

\section{Effect of Free acidity}

Investigation of free acidity effect was achieved by varying acid strength from $0.25 \mathrm{M}$ to $3 \mathrm{M}$, at 3:1 ratio of hydrogen peroxide (Caro's acid) at constant, temperature $\left(40^{\circ} \mathrm{C}\right)$, particle size $(300 \mu \mathrm{m}), 1: 2$ solid liquid ratio and stirring speed (300 rpm) for $6 \mathrm{hr}$. Uranium concentration and Eh were analyzed after solid liquid separation at each experiment. The obtained data was graphed as the following Figs. 5 and 6 .

$\left(\mathrm{H}_{2} \mathrm{SO}_{4}\right.$ and Caro's acid) on uranium leachability $\left(\mathrm{H}_{2} \mathrm{SO}_{4}\right.$ and Caro's acid $)$

As shown in Fig. 5, the mineralized ore need large amounts of sulfuric acid to achieve almost uranium leaching. Since the leachability record low percent 9 to $19 \%$ at free acidity $0.25 \mathrm{M}$ to $1 \mathrm{M}$ with redox potential 215 to $275 \mathrm{mv}$ then increase periodically as in Fig. 6 . Which; owing to the studying mineralized ore containing a lot of acid consumer minerals such as fluorite mica.

Introducing the oxidant as $\mathrm{H}_{2} \mathrm{O}_{2}$ mixed with sulfuric acid as the leach liquor improve the leaching performance and increase the leachability from 19 to $41 \%$ and redox potential from 275 to $425 \mathrm{mv}$. Since increase the oxidation rate of iron consequently increase the uranium dissolution. In other hand, reduce consuming of sulfuric acid by gangues metals associated uranium and oxidation. $1 \mathrm{M}$ sulfuric acid was used as the maximum concentration of ore leaching to decrease the dissolution of gangues metals such 
as silica and alumina which exist as the major oxides in ore. High free acidity, access to the uranium inside individual particles.

\section{Effect of contact time}

By varying the parameter in the range of 3-7 hr with keeping other variables as follows: $1 \mathrm{M}$ free acidity, temperature $40^{\circ} \mathrm{C}$, particle size $300 \mu \mathrm{m}$ and solid/liquid ratio 1:2.

The results are shown in Fig. 7, about 31.5, 17 \% of uranium values were leached in 3 hr using $1 \mathrm{M} \mathrm{H}_{2} \mathrm{SO}_{4}$ and Caro's acid respectively. Then, gradually increased to about 41.8, and $19.5 \%$ in $4-7 \mathrm{hr}$ reaction time, respectively. The less increase in leachability of uranium is result of simultaneous increase of acid consumption, during leaching in case of using only sulfuric acid since.

\section{Effect of grain size}

The leachability as function of grain size was established by varying the grain size from 425 to $75 \mu \mathrm{m}$ and constant the other parameters and illustrated in Fig. 8. As shown in Fig. 7, the leachability increase gradually with grain size decrease could be attributed to increase in the area of reaction consequently increase dissolution of the contained uranium and oxidant (MnO) on solution.

\section{Effect of temperature}

Temperature studied range were from room temperature to lower $85^{\circ} \mathrm{C}$ to avoid dissolution of associated minerals like monazite and rare earth silicate [40]. Consequently, temperature effect was investigated by varying reaction temperature from 30 to $70^{\circ} \mathrm{C}$ and fixing the other parameters to avoid dissolution of associated minerals like monazite and rare earth elements silicate .Consequently, temperature effect was investigated by varying reaction temperature. Figure 9, shows that, gradual increase in uranium leachability with temperature increase, as increase from 19.2 to $36 \%$ at temperature from 30 to $70{ }^{\circ} \mathrm{C}$ in case of diluted $\mathrm{H}_{2} \mathrm{SO}_{4}$. On using Caro`s acid ,there is slightly increase in leachability from 41 to 44 at temperature $30-50{ }^{\circ} \mathrm{C}$, then tend to decrease with temperature increase from 50 to $70{ }^{\circ} \mathrm{C}$.

From above, we can concluded that the high temperature accelerate the uranium dissolution when using diluted $\mathrm{H}_{2} \mathrm{SO}_{4}$. On other hand, accelerate firstly then decrease after that on using Caro's acid which can be attributed to the dissociation of $\mathrm{H}_{2} \mathrm{SO}_{5}$ into $\mathrm{H}_{2} \mathrm{SO}_{4}$ and water at temperature above $50{ }^{\circ} \mathrm{C}$.

\section{Effect of $S / L$ ratio}

The effect of $S / L$ ratio was investigated by varying through the $S / L$ ratio range between $1: 2$ to $1: 5$, while fixing the other parameters. The obtained results (Fig. 10) show that the uranium leachability increased gradually as the ratio decrease from $1: 2$ to $1: 5$ in case of $\mathrm{H}_{2} \mathrm{SO}_{4}$. On other hand, multiplied as ratio decrease from $1 / 2$ to $1 / 3$ then increase gradually to reach $96.5 \%$ from $1 / 3$ to $1 / 5$ ratio. Which proved that the Caro's acid save in sulfuric acid consuming during leaching and give concentrated uranium leach liquor. 


\section{Leaching kinetics}

In order to gain more understood of leaching behavior, the uranium leachability \% values were determined along each experiment performed with time. The obtained results would be formulated in core shrinking models which the best model can describe the kinetics and reaction mechanism.

Shrinking core model derived equations as the following [46].

$1-3(1-X) 2 / 3+2(1-X)=K_{d} t,(5)$

when the leaching rate controlled by diffusion through product layer

$1-(1-X) 1 / 3=K_{c} t,(6)$

when the leaching rate controlled by chemical reaction on surface layer

$X=K_{f},(7)$

when leaching rate controlled by film diffusion

While $\mathrm{K}_{\mathrm{d}}, \mathrm{Kc}$ and $\mathrm{K}_{\mathrm{f}}$ are the apparent rate constants $\left(\min ^{-1}\right), t$ is the leaching time, and $X$ is the metal fraction.

\section{Effect of free acidity}

To elucidate the mechanism of the Caro's acid concentration on uranium dissolution, the shrinking core models as described by Eqs. (5) and (6) are operated and graphed as in Fig. (11 a,b).

\section{(a) diffusion reaction control; (b) Chemical reaction control}

As shown in Fig. $11 a, b$,there are a linearity relation of slopes $>0.9$ between the uranium fraction mole dissolved at varied times and Caro's acid concentration. There are very little changes between two reaction models, so that another relationship will be plotted between logarithm apparent rate constant against logarithm $\mathrm{M} \mathrm{H}_{2} \mathrm{SO}_{4}$ as in Fig. 12, to differentiate between them.

Figure 12, shows that the linearity in diffusion model than other chemical one, which proved that the leaching rate is controlled by diffusion process. The slope of 0.986 indicates strong dependence of the rate on sulfuric acid concentration.

\section{Effect of Temperature}

Measuring uranium adsorbed each time interval during dissolution experiments with varying reaction temperature and fixes other conditions. The obtained resulted used in construction of two shrinking core models to be examined at different temperatures as shown Fig. 13a,b. 
As observed, the two models have good linear fits and their $\mathrm{R}^{2}$ values are close to each other. Therefore, it is difficult to distinguish between these reaction models.

Activation energy is the important parameter that can be used to justify the rate-determining step in hydrometallurgical process. It was calculated based on the Arrhenius equation [47]:

$K=A e^{-E a / R T} ; \operatorname{LnK}=L n A-E a / R T(8)$

Where $K$ is the rate constant, Ea is the activation energy, $R$ is the ideal-gas constant $(8.314 \mathrm{~J} / \mathrm{Kmol}), T$ is the temperature in $\mathrm{K}$ and $A$ the frequency or pre-exponential factor.

As shown in Fig. 14, Arrhenius equation was plotted as $\operatorname{Ln}(\mathrm{K})$ versus $(1 / \mathrm{T})$ for each temperature, and the activation energies were calculated from the slopes of straight lines where the slope is $-E a / R$.

From above Figure the calculated activation energy Ea are -11.03 and $-8.48 \mathrm{~kJ} / \mathrm{mole}$ for chemical reaction control and diffusion reaction control respectively. These indicate that the reaction rate is controlled by chemical reaction on the particle surface. Consequently, temperature have pronounced effect on reaction rate since, its increase lead to dissociate the Caro's acid into $\mathrm{H}_{2} \mathrm{O}$ and $\mathrm{H}_{2} \mathrm{SO}_{4}$ on the particle surface, then increase the diffusion of ions dissociated through the liquid film and particle layer.

\section{Conclusion And Future Applications}

Batch experiments show the superiority of Caro's acid in uranium dissolution with low concentration than dilute sulfuric acid. Leachability of $91.5 \%$ and $52 \%$ uranium for Caro's acid and dilute sulfuric acid respectively was obtained. Shrinking core models used to determines the reaction mechanism, which shows that the uranium dissolution in Caro's acid controlled by diffusion reaction model. Arrhenius plot were constructed to calculate the activation energy, which is found ranging from -11.03 to $-8.48 \mathrm{kj} / \mathrm{mole}$. In future, we can applied a two-stage leaching for achieving maximum uranium solubilisation with minimum dissolution of gangue elements like chlorite and biotite in sulfuric acid leaching of uranium ore. Firstly, leaching with Caro's with optimized concentration of less than $100 \mathrm{~g} / \mathrm{l} \mathrm{H}_{2} \mathrm{SO}_{4}$ until Eh and $\mathrm{pH}$ of leach liquor reached 450 and 1.6 respectively followed by leaching with diluted $\mathrm{H}_{2} \mathrm{SO}_{4}$ that keep the Eh and $\mathrm{pH}$ of leach liquor at the same values.

\section{Declarations}

\section{Conflict of Interests}

The authors declare that they have no known competing financial interests or personal relationships that could have appeared to influence the work reported in this paper.

\section{References}


1. -Abdel Meguid AA, Cuney M, Ammar SE, Ibrahim TM, Ali KG, Shahin HA, Omer SA, Gaafar IM, Masoud SM, Khamis AA, Haridy MH, Kamel Al, Abdel Gawad AE, Abu Donia AM, Bayoumi MB, Aly EM (2003) Uranium potential of Eastern Desert granites, Egypt. Internal Report. Nuclear Materials Authority, Cairo

2. -Attawyia MY, El Mezayen AM, Hassan MM, Hashad AH. Ammar FA (1989) On the metamorphism of the gneisses and metasediments, in South Eastern Desert. Egypt Bull Fac Sci Zagazig Uni V 11:194$224 \mathrm{p}$

3. -Awad NT (1994) Kyanite in quartz segregation in the Central Eastern Desert, Egypt. Egyptian Minerals 6,:77-94

4. -Rashed MA (2005) Geologic Studies on A New Occurrence of Nuclear Materials in Abu Rushid area, South Eastern Desert, Egypt. PhD. Thesis. Faculty of science, Mansoura Univ (Demiatta)

5. -Ibrahim ME, Saleh GM, Ibrahim WS (2010) Low grade metamorphosed sandstone-type uranium deposit, Wadi Sikait, South Eastern Desert, Egypt. Journal of Geology Mining Research 2(6):129-141

6. -Saleh GM (1997) The potentiality of uranium occurrences in Wadi Nugrus area, south Eastern Desert, Egypt. Ph. D. Thesis Mans. Univ. $171 \mathrm{p}$

7. -Stern RJ, Hedge CE (1985) Geochronological and isotopic constraints on late Precambrian crustal evolution in the Eastern Desert of Egypt. Am J Sci 285:97-127

8. -Surour AA (1995) Medium to high. Pressure amphibolites from G. Zabara and Wadi Sikait, south Eastern Desert, Egypt. J of African Earth Sci 21:443-457

9. -Kinnaird JA, Nex P (2008) Assessing the Geological Occurrences of Uranium in Africa Implications for Mining and Processing, Uranium Mining and Exploration Conference, Johannesburg

10. -Yan D, Connelly D (2008) Implications of Mineralogy on Uranium Ore Processing. ALTA 2008 Uranium Conference, Perth, Western Australia

11. -Anonyms (1973) Uranium extraction technology. Technical Rept. IAEA, Vienna, p 359

12. -Born CA, Queneau PB, Ronzio RA (1975) Processing of wolframite cassiterite concentrate for brannerite removal. Trans Soc Min Eng AIME 258(3):218-221

13. - International Atomic Energy Agency Vienna (1985) Advances in uranium ore processing and recovery from non-conventional resources

14. -Lunt D, Holden A (2006) Uranium Extraction The Key Issues for Extraction, ALTA Uranium Conference, Perth, Western Australia

15. -Merritt RC (1971) The Extractive Metallurgy of Uranium. Colorado School of Mines

16. -Lucas GC, Fulton EJ, Vautier FE, Waters DJ, Ring RJ (1983) Queensland Mines Plant Trial with Caro's Acid, Proc. Australas. Inst. Min. Metall., 287, September

17. -Broekman BR, Ward B (1984) The modeling of the uranium leaching and ion exchange processes at the Hartebeestfontein gold mine and its role in economic plant operation", Mintek 50 (Proc. Conf. Sandton, The Council for Mineral Technology, Randburg, South Africa 551-556 
18. -Abdel-Hamied MA, Abu El Azm MG, Orabi AH (2012) Recovery of Uranium from Abu-Rushied Granitic Rocks Using Diluted Phosphoric Acid Leaching Agent. Arab Journal of Nuclear Sciences and Applications, 45(2): 97-116.

19. -Mahmoud KF, Nagar MS, Walied MM (2017) Leaching of Uranium from Abu-Rusheid Mylonite Eastern Desert, Egypt. Scientific Internal Report, Nuclear Materials Authority, Cairo, Egypt

20. -Stein M, Goldstein SL (1996) From plume head to continental lithosphere in the Arabian-Nubian shield. Nature 382:773-778

21. -Kusky TM, Abdelsalam M, Stern RJ, Tucker RD (2003) Preface: evolution of the East African and related orogens, and the assembly of Gondwana. Precambrian Res 123:81-85

22. -Stern RJ (1994) Arc-assembly and continental collision in the Neoproterozoic African orogen: implications for the consolidation of Gondwanaland. Annu Rev Earth Planet Sci 22:319-351

23. -Stern RJ, Avigad D, Miller NR, Beyth M (2006) Evidence for the Snowball Earth hypothesis in the Arabian-Nubian Shield and the East African Orogen. J Afr Earth Sci 44:1-20

24. -Johnson PR, Woldehaimanot B (2003) Development of the Arabian- Nubian Shield: perspectives on accretion and deformation in the northern East African Orogen and the assembly of Gondwana. In: Yoshida M, Dasgupta S, Windley B (eds) Proterozoic East Gondwana: supercontinent assembly and breakup. Geol. Soc. Lond., Special Publications 206: 289-325

25. -Abdelsalam MG, Stern RJ (1996) Sutures and shear zones in the Arabian-Nubian Shield. J Afr Earth Sci 23:289-310

26. -Stern RJ (2002) Crustal evolution in the East African Orogen: a neodymium isotopic perspective. J Afr Earth Sci 34:109-117

27. -Stoeser DB, Frost CD (2006) Nd, Pb, Sr, and O isotopic characterization of Saudi Arabian Shield terranes. Chem Geol 226:163-188

28. -Hassan MA (1964) Geology and petrographical studies of the radioactive minerals and rocks in Wadi Sikait-Wadi El Gemal area. Eastern Desert, U. A. R: M. Sc. Thesis faculty of science, Cairo Univ. $165 p$

29. -El-Shazly EM, Hassan MA (1972) Geology and radioactive mineralization at Wadi Sikait- Wadi El Gemal area. South Eastern Desert. Egypt J Geol 2:201 p

30. -Hashad AH, Hassan MA (1959) Report on the prospection work carried out in Wadi El Gemal area, south Eastern Desert, Egypt. Internal Report. AEE, Cairo

31. -Greiling RO, Kroners A, El-Ramly MF, Rashwan AA (1988) Structural relations between the southern and central parts of the Eastern Desert of Egypt: details of an fold and thrusts belt. In: El-Gaby S, Greiling R (eds) The Pan-African Belt of the NE Africa and Adjacent Areas. Tectonic Evolution and Economic Aspects. Freidr. Vieweg \& Sohn, Braunschweig/Weisbaden, pp 121-145

32. -Fritz H, Wallbrecher E, Khudeir AA, Abu El-Ela FF, Dallmeyer DR (1996) Formation of Neoproterozoic metamorphic core complexes during oblique convergence Eastern Desert. Egypt J African Earth Sci 23:311-329 
33. -Fowler A, Osman AF (2009) The Sha'it-Nugrus shear zone separating central and south Eastern Deserts, Egypt: A post-arc collision low-angle normal ductile shear zone. J Afr Earth Sc 53:16-32

34. -Hassan MA (1973) Geology and geochemistry of radioactive columbite-bearing psammitic gneiss of Wadi Abu Rusheid South Eastern Desert, Egypt, Annals of the Geological Survey of Egypt, III: 207225

35. -Abdel-Monem AA, Hurley PM (1979) U-Pb staing of zircons from psammitic gneisses, Wadi Abu Rusheid-WadiSikait area, Egypt, Institute of Applied Geology, Jeddah, 3 (2): pp 165-170

36. -Hilmy ME, El Bayoumi RM, Eid AS (1990) Geology, geochemistry, and mineralization of the psammitic gneiss of wadi Abu Rusheid, Eastern Desert, Egypt. Jour. Afr. Earth Sci., V.II, p.197-205

37. El-Naby -Abd, Frisch H W (2006) Geochemical constraints from the Hafafit Metamorphic Complex (HMC): evidence of Neoproterozoic back-arc basin development in the central Eastern Desert of Egypt. Journal of African Earth Science 45:173-186

38. -Shalan AS (2016) Subsurface geological and geochemical studies with uranium distribution for some boreholes in Abu-Rusheid uranium occurrence, Southern Eastern Desert, Egypt. Ph.D Thesis, AlAzhar Univ. 94p

39. -Ibrahim ME, Saleh GM, Amer T, Mahmoud FO, Abu El Hassan AA, Ibrahim IH, Aly MA, Azab MS, Rashed MA, Khaleal FM, Mahmoud MA (2004) Report on uranium and associated rare metals potentialities of Abu Rusheid brecciated shear zone II, South Eastern Desert, Egypt. (Internal report, Nuclear Materials Authority, Cairo, Egypt)

40. -Shapiro L, Brannok WW (1975) Rapid analysis of Silicate, Carbonate and Phosphate rocks. Revised edition. U.S. Government Printing office

41. -Marczenko Z (1976) Spectrophotometric Determination of Elements. John Wiley \&Sons Inc., New York. Part II.537-587 pp

42. -Eberle AR, Lerner MW, Cold beck CG, Rodden CJ (1964) Titrimetric Determination of Uranium in Product, Fuel and Scrap Materials After Ferrous Iron Reduction in Phosphoric Acid, New Brunswick Laboratory, USAEC

43. -Nicol MJ, Needs CRS, Finkelstein NP (1975) Electrochemical model for the leaching of uranium dioxide: acid media, Leaching and Reduction in Hydrometallurgy (BURKIN, A.R., Ed.), Institute of Mining and Metallurgy, London 1-11

44. -Ritcey GM (1983) Candian uranium Proceedures 'Mettalurgical Committee Meeting, Bancroft, Ontario

45. -Onyedika G, Nwoko C, Oguarah A, Ogwuegbu M (2013) Comparative Kinetics of Iron Ore Dissolution in Aqueous $\mathrm{HCl}-\mathrm{HNO} 3$ System. Journal of Minerals Materials Characterization Engineering 1:153159

46. -Que W, Tan Y, Zeng Y, Wang S (2002) Geochemical kinetics and mass transport of in situ uranium leaching. Atomic Energy Press, Beijing

47. -Adebayo AO, Olasehinde EF (2015) Leaching kinetics of lead from galena with hydrogen peroxide and sodium chloride solution. Trans Inst Min Metall Sect C 124:137-142 

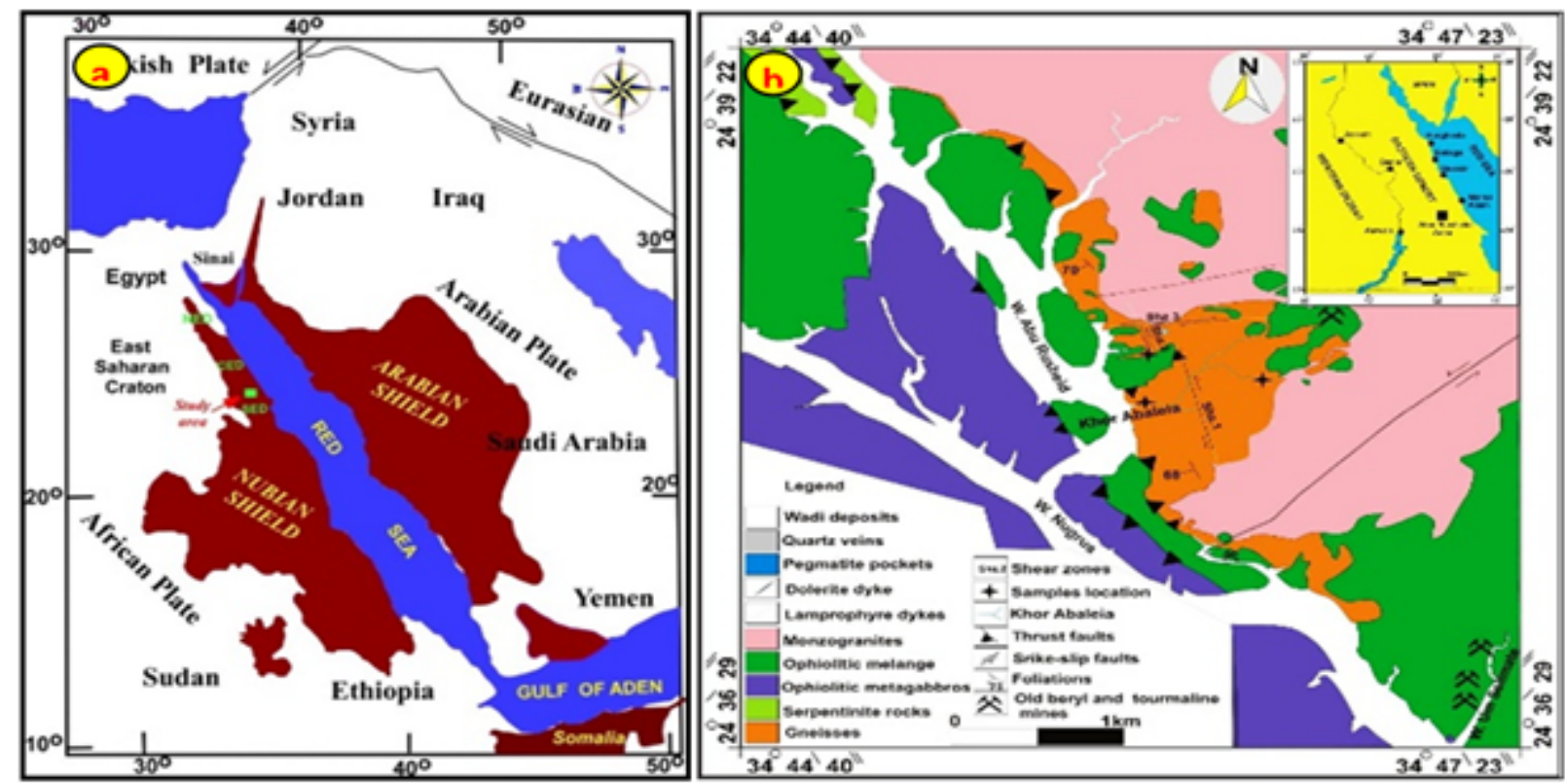

Figure 1

(a) Map of the Arabian-Nubian Shield (ANS) modified after [23]. (b) Geologic map of Abu Rusheid area, SED, Egypt, after [39].

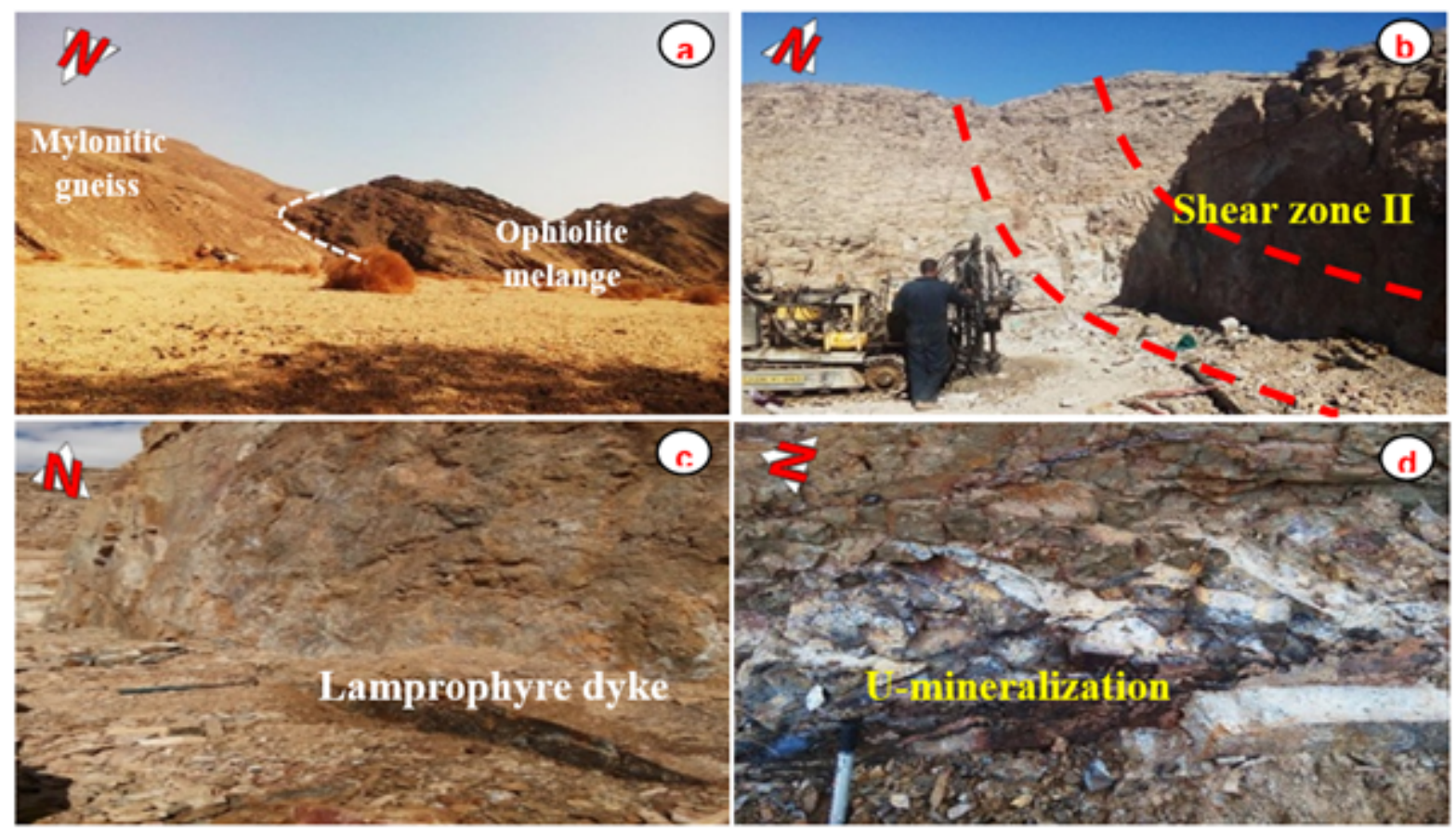

Figure 2

Field photographs showing, (a) Ophiolitic melange thrusted over mylonitic gneiss. b) NNW shear zone. (c) Lamprophyre dyke. (d) Altered lamprophyre dyke associated with secondary uranium mineralization. 

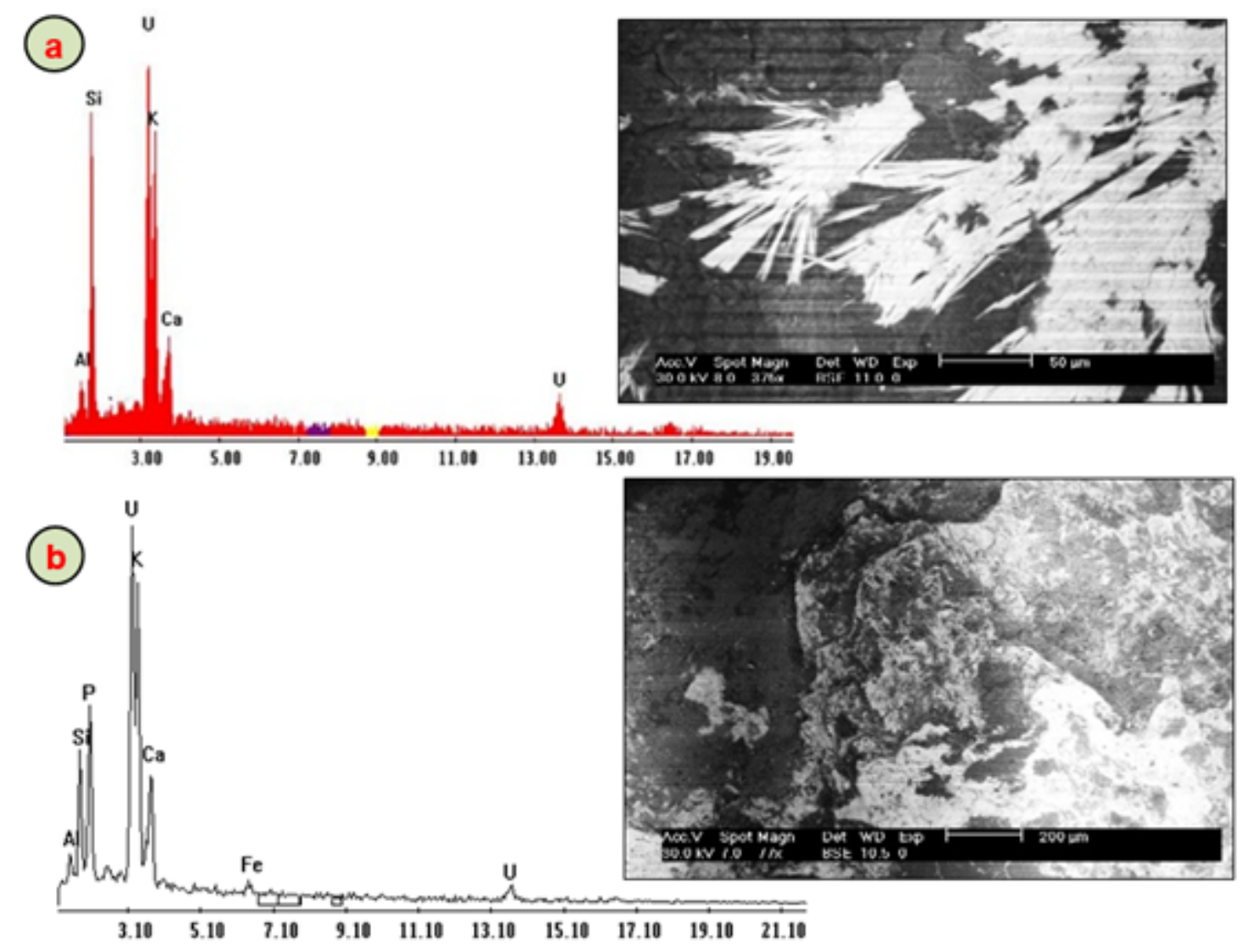

\section{Figure 3}

ESEM Micrograph and EDX chart of, a) - Uranophane and b) -Autunite of investigated rocks at Abu Rusheid area.
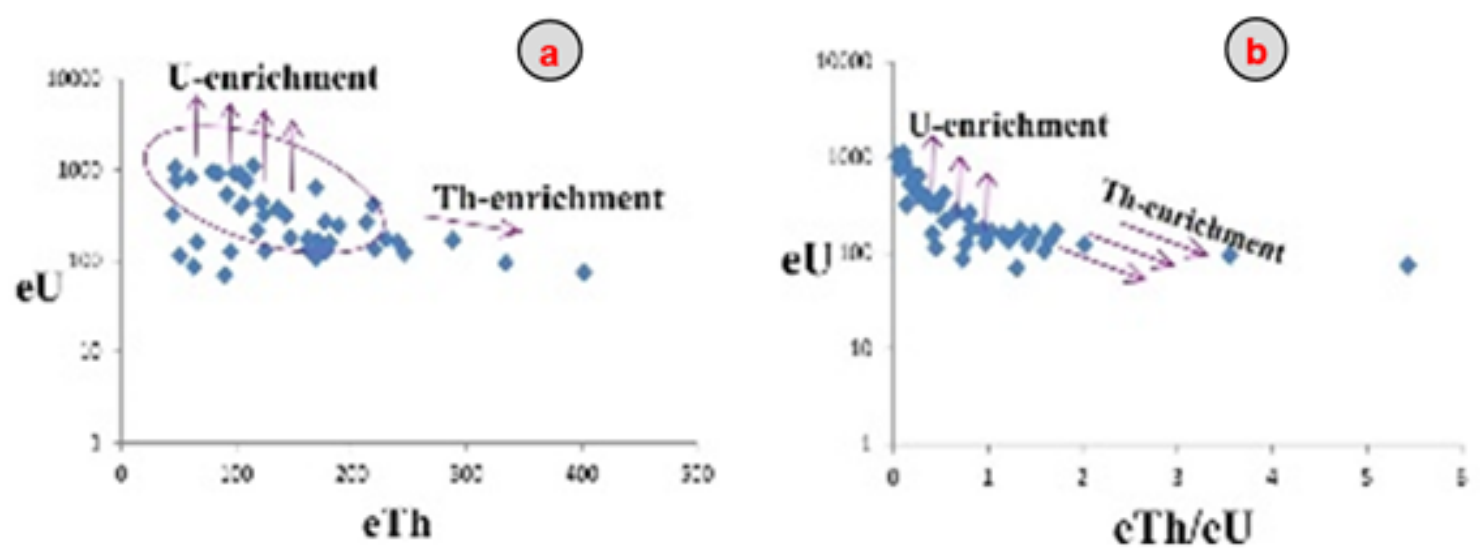

\section{Figure 4}

Radioelements variation diagrams for the mylonitic gneiss rocks, Abu Rusheid area, SED, Egypt. a- eU vs eTh b- eU vs eTh/eU. 


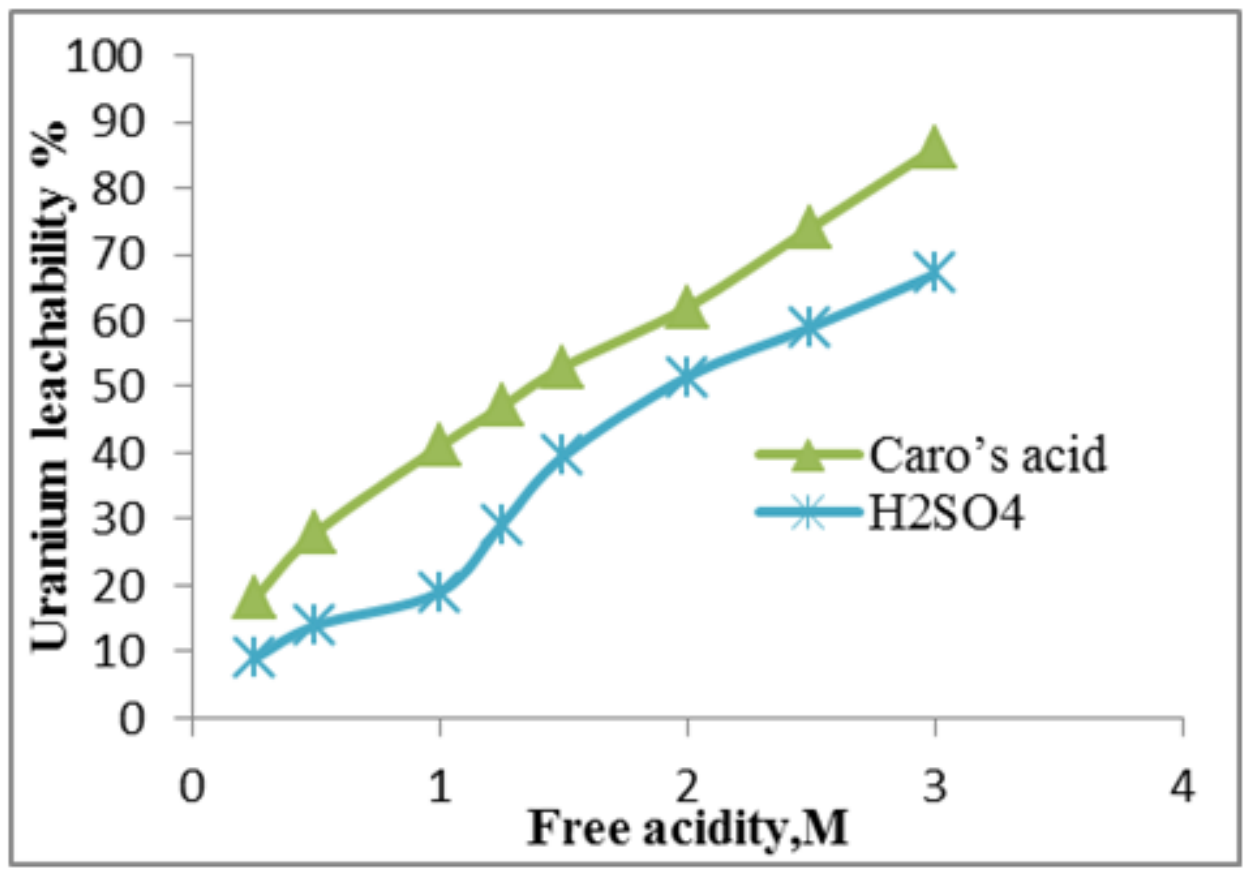

Figure 5

Effect of free acidity of leach solution ( $\mathrm{H} 2 \mathrm{SO} 4$ and Caro's acid) on uranium leachability

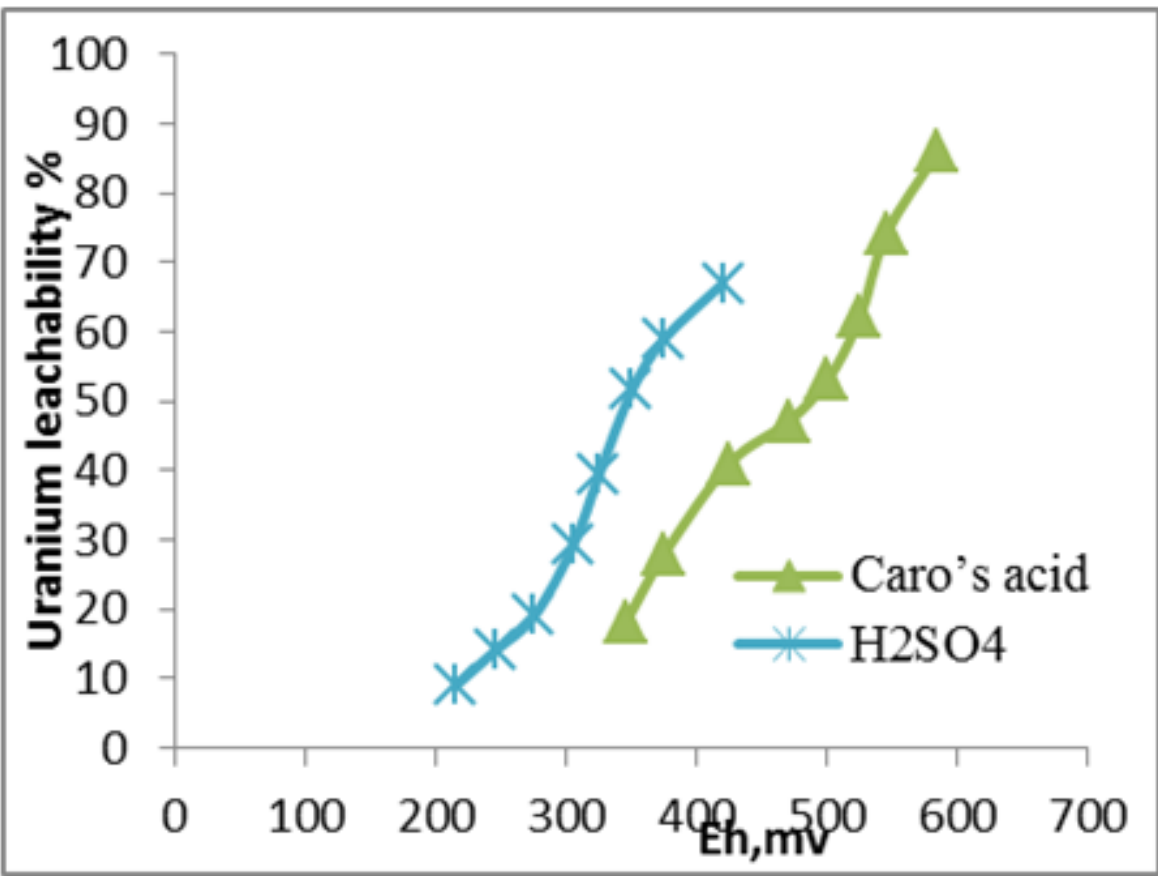

Figure 6

Effect of Eh on uranium leachability (H2SO4 and Caro's acid) 


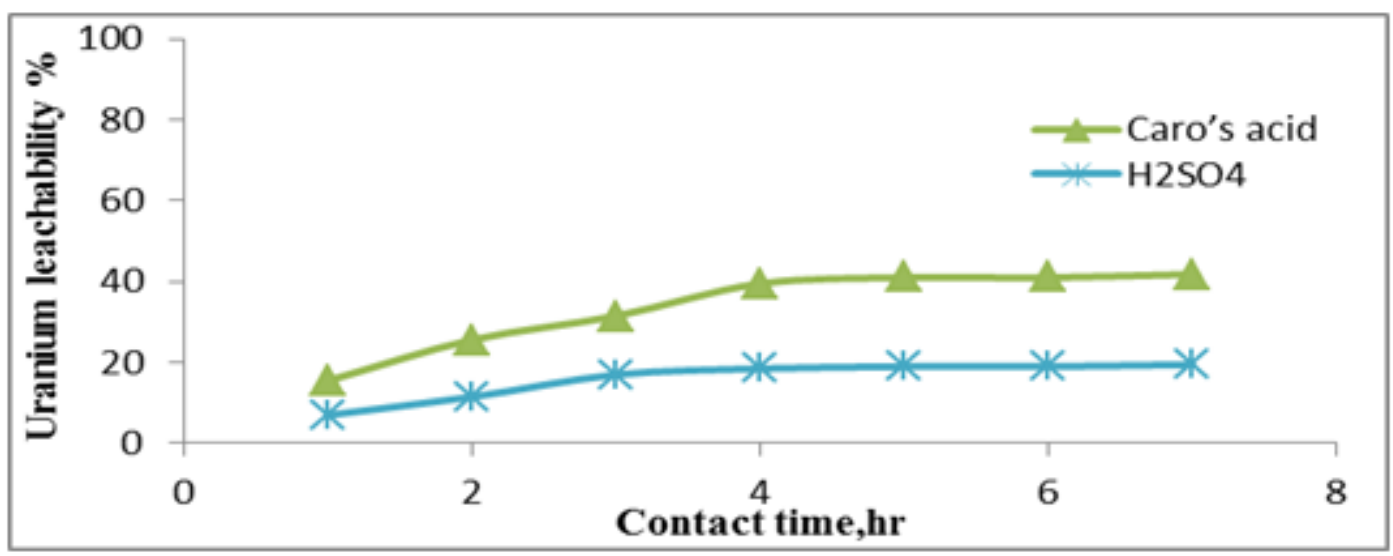

Figure 7

Effect of contact time on uranium leachability \%using H2SO4 and Caro's acid

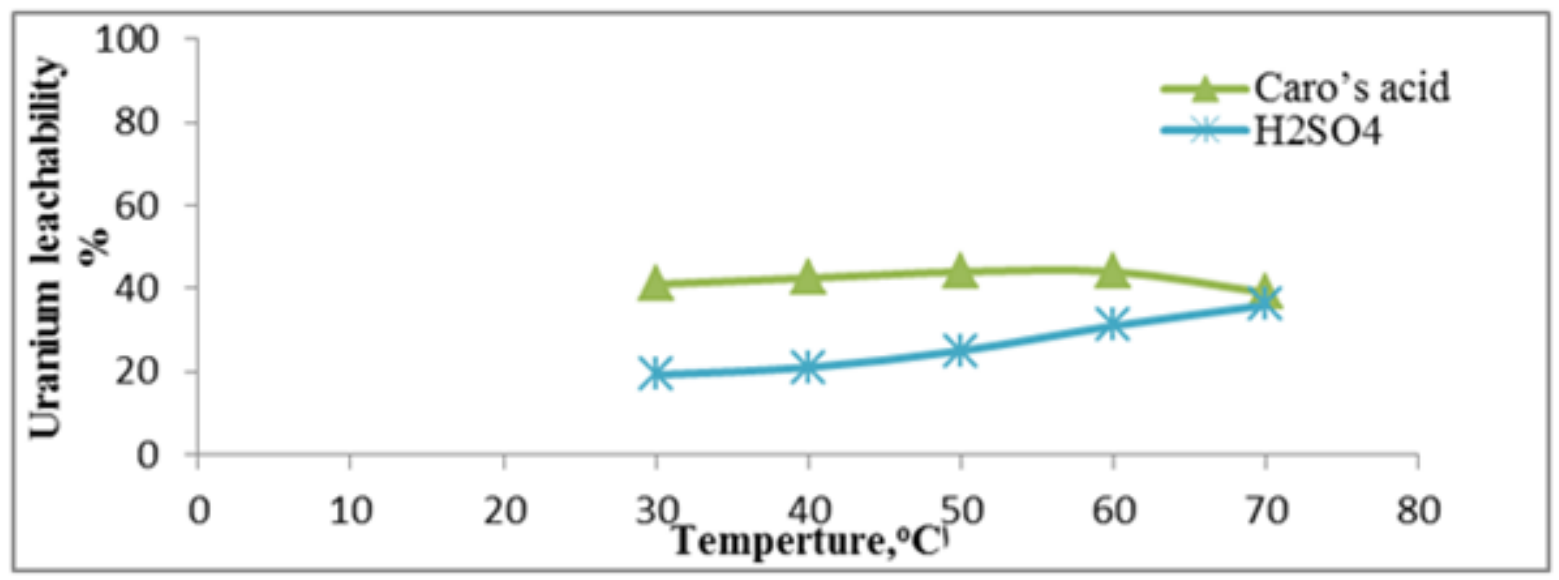

Figure 8

Effect of grain size on uranium leachability \%using H2SO4 and Caro's acid

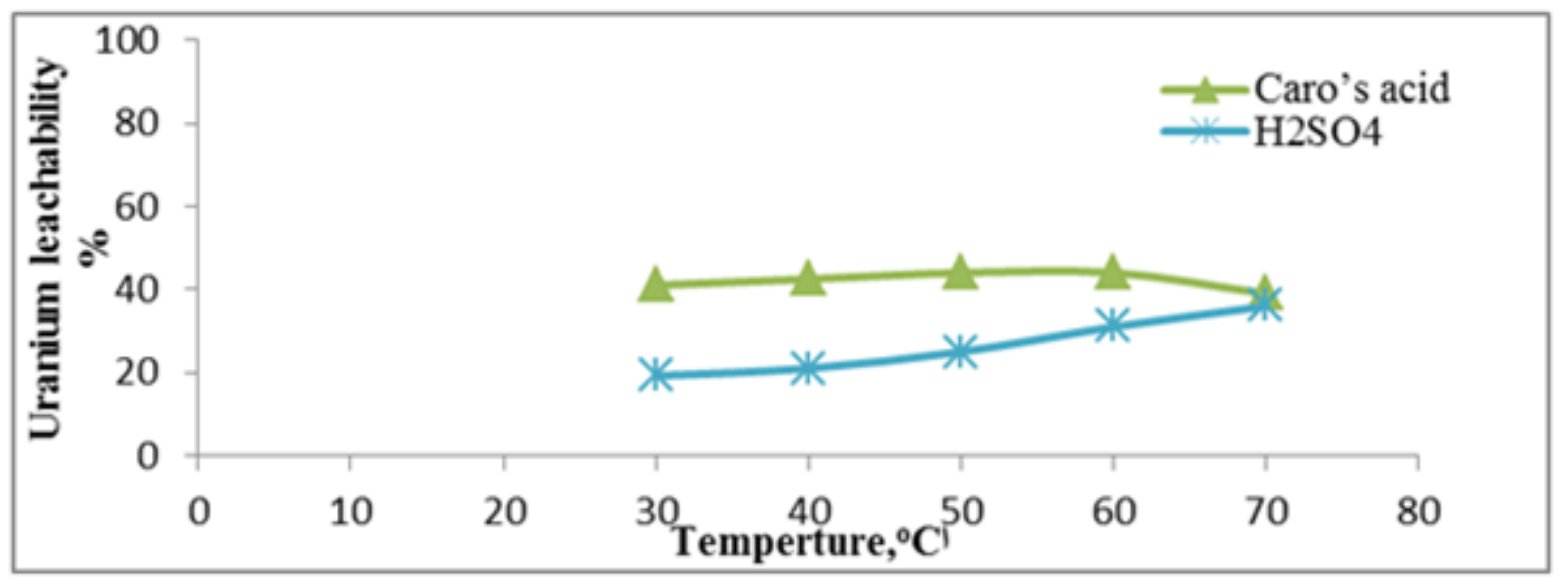

Figure 9

Effect of Temperature on uranium leachability \%using H2SO4 and Caro's acid 


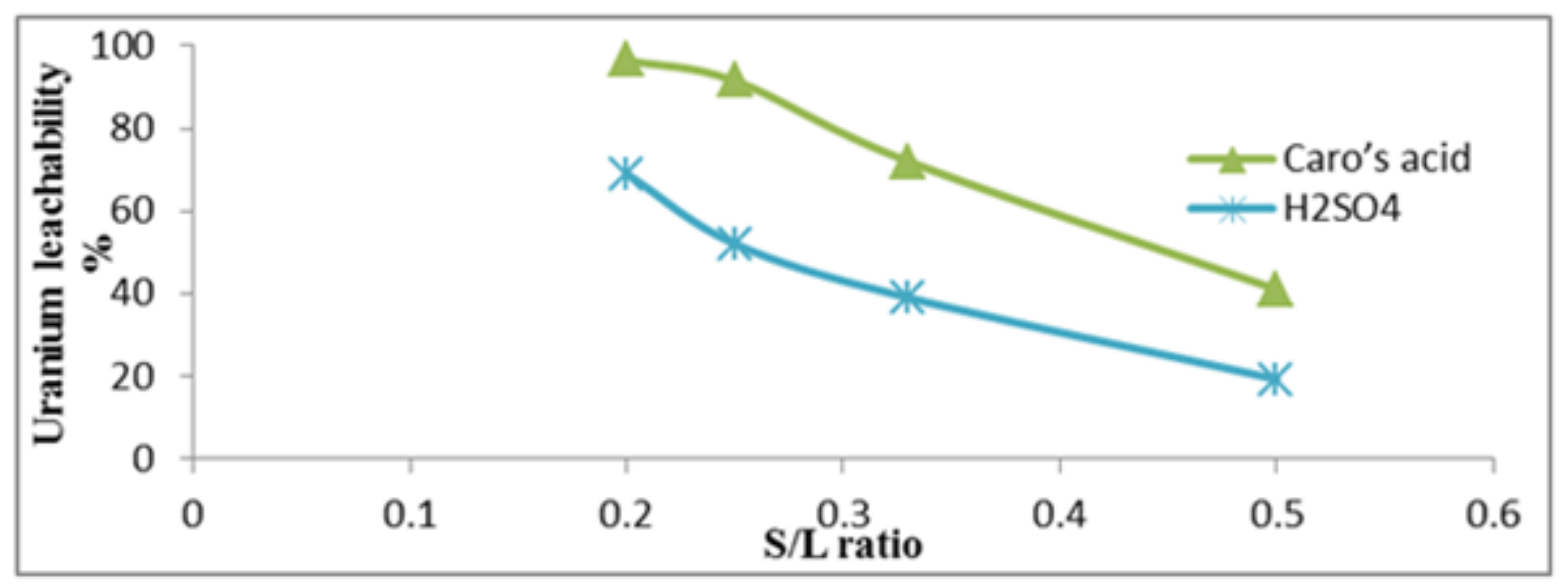

\section{Figure 10}

Effect of S/L ratio on uranium leachability \% using $\mathrm{H} 2 \mathrm{SO} 4$ and Caro's acid
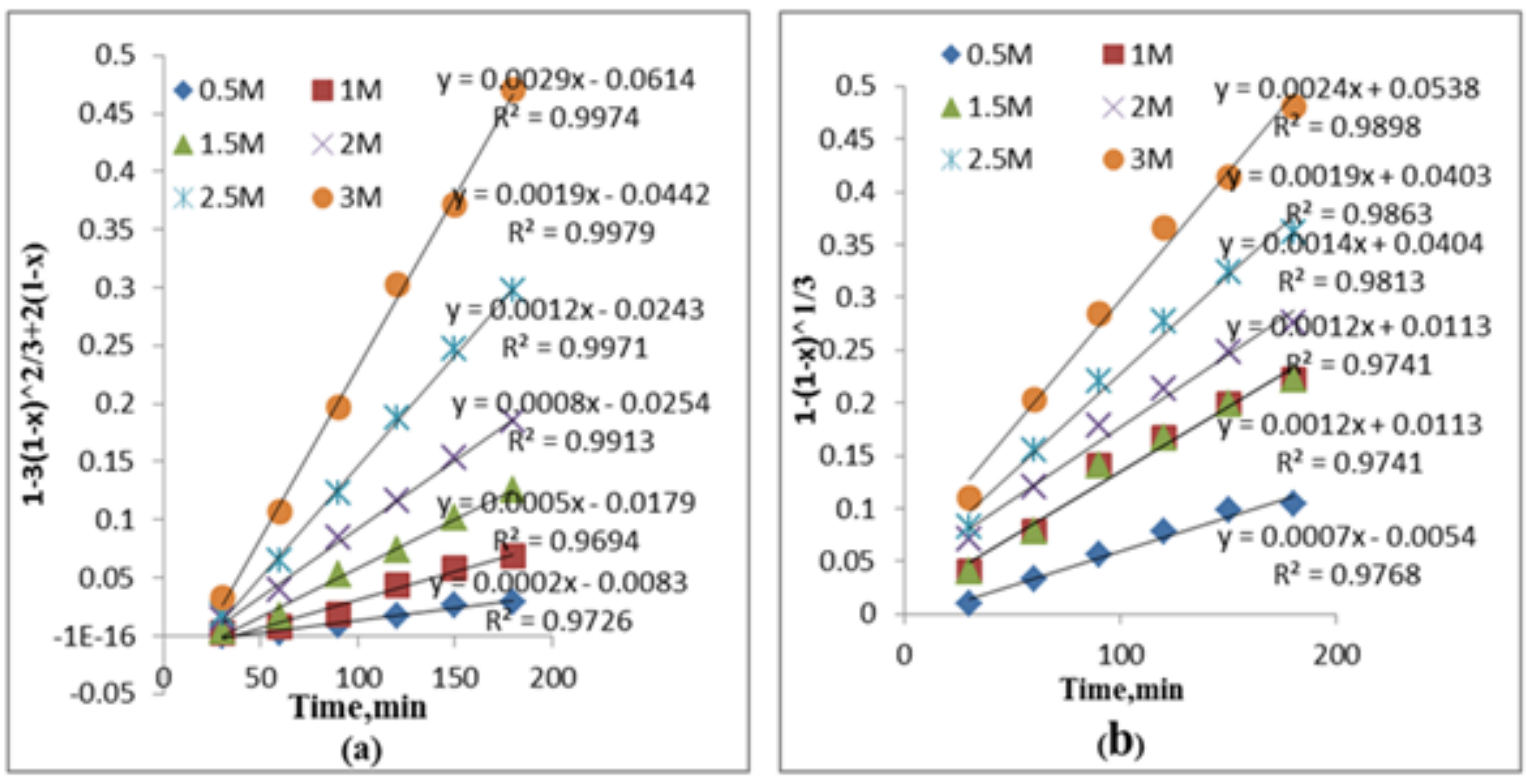

\section{Figure 11}

The kinetic curve of uranium leaching at different concentration of Caro's acid based on different models.

(a) diffusion reaction control; (b) Chemical reaction control
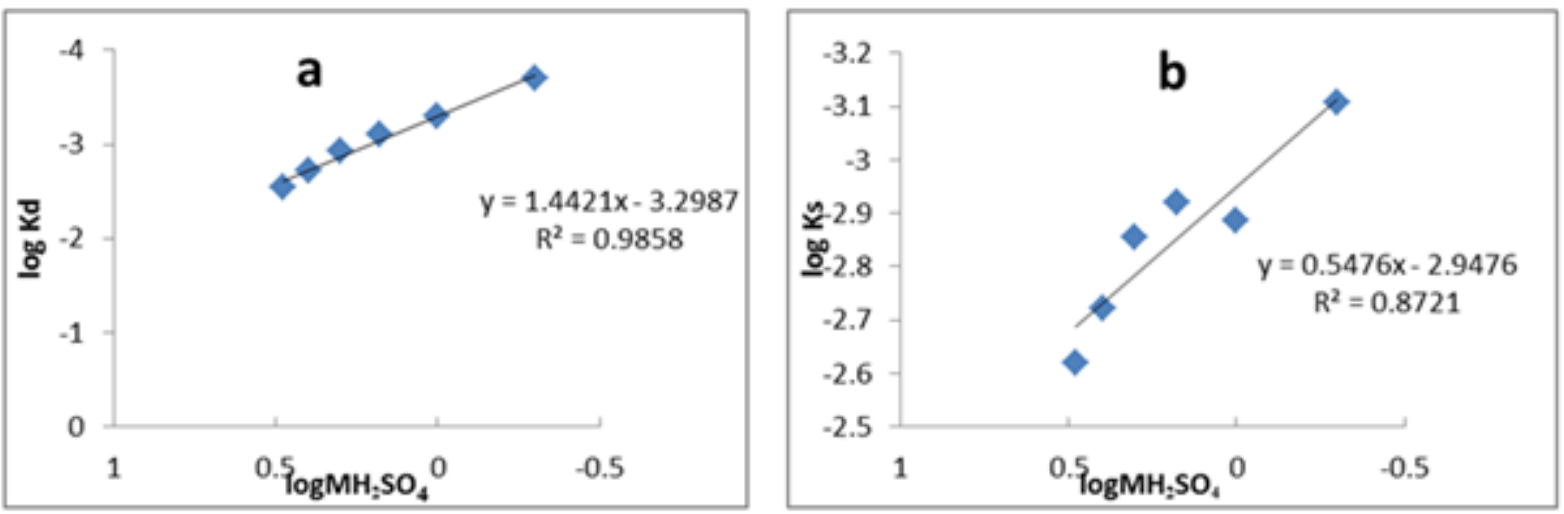

Page 20/21 
Figure 12

log-log plot of the rate constant versus $\mathrm{H} 2 \mathrm{SO} 4$ concentration based on different models .(a) diffusion reaction control; (b) Chemical reaction control
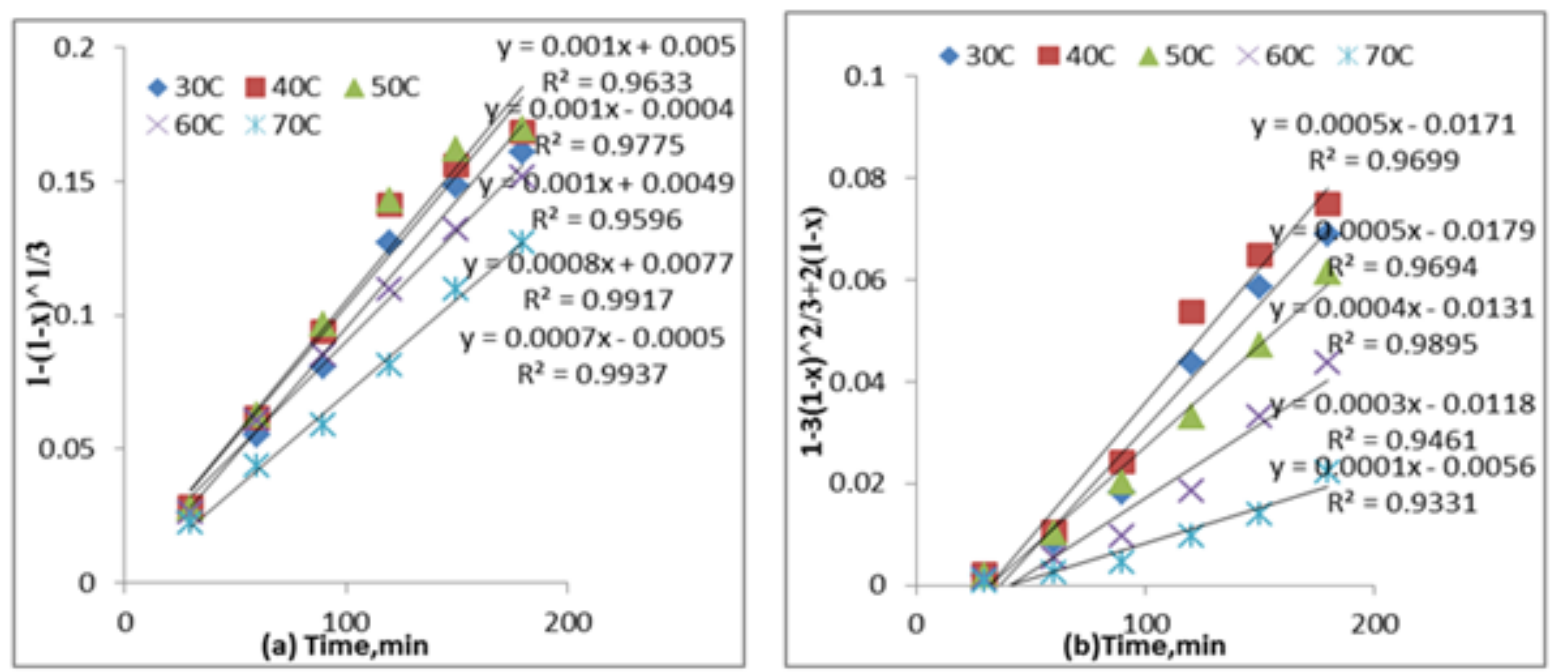

Figure 13

The kinetic curve of uranium leaching at different temperatures based on different models (a) Diffusion reaction control; (b) Chemical reaction control
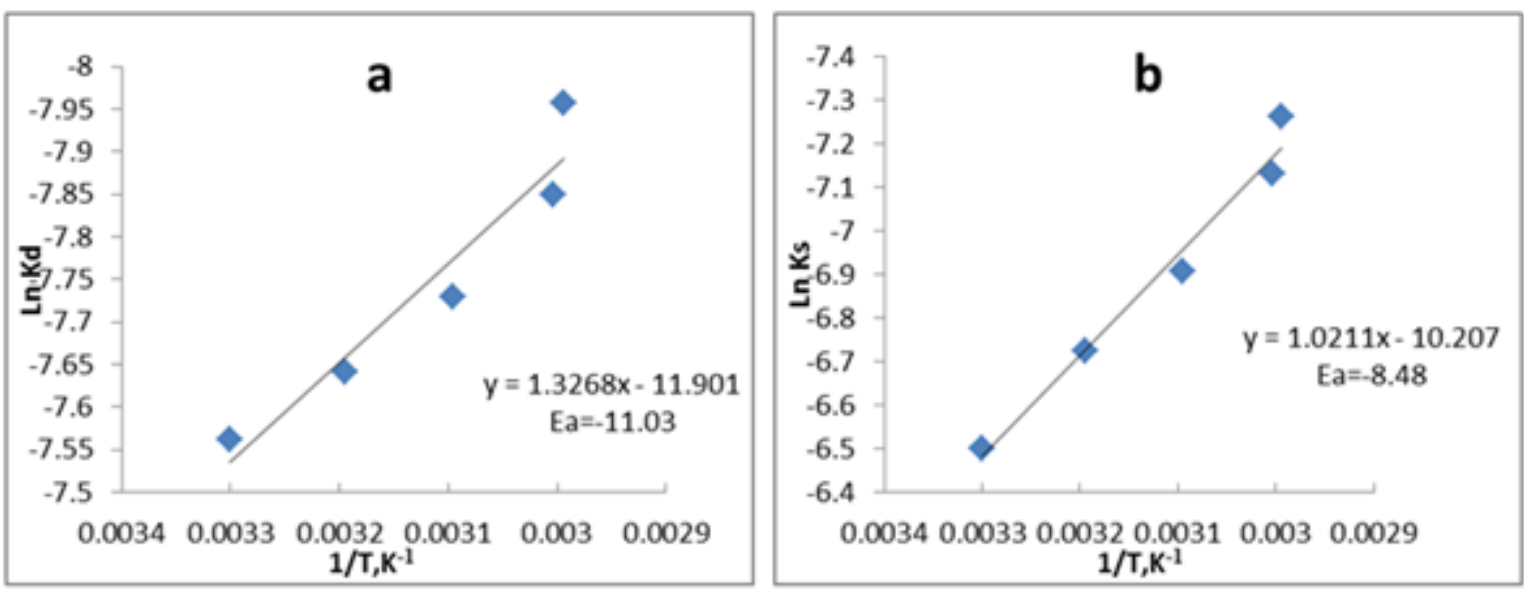

Figure 14

Arrhenius plot for the uranium leaching at different Temperatures based on different models (a) Diffusion reaction control; (b) Chemical reaction control 